\title{
Renal extramedullary hematopoiesis: interstitial and glomerular pathology
}

\author{
Mariam P Alexander ${ }^{1}$, Samih H Nasr ${ }^{1}$, Paul J Kurtin ${ }^{2}$, Edward T Casey ${ }^{3}$, \\ Loren P Herrera Hernandez ${ }^{1}$, Mary E Fidler ${ }^{1}$, Sanjeev Sethi ${ }^{1}$ and Lynn D Cornell ${ }^{1}$ \\ ${ }^{1}$ Division of Anatomic Pathology, Department of Laboratory Medicine and Pathology, Mayo Clinic, Rochester, \\ MN, USA; ${ }^{2}$ Division of Hematopathology, Department of Laboratory Medicine and Pathology, Mayo Clinic, \\ Rochester, MN, USA and ${ }^{3}$ Division of Nephrology and Hypertension, Mayo Clinic, Rochester, MN, USA
}

\begin{abstract}
Renal extramedullary hematopoiesis is rarely recognized in the antemortem setting. We identified 14 patients with renal extramedullary hematopoiesis on antemortem specimens from 1994 to 2015. The mean age was 68 years (range 47-87 years); males predominated $(M: F=9: 5)$. All presented with renal insufficiency, including five (36\%) with acute kidney injury. The mean serum creatinine at biopsy was $2.9 \mathrm{mg} / \mathrm{dl}$ (range $1.2-7.3 \mathrm{mg} / \mathrm{dl}$ ). All had proteinuria (mean $7.9 \mathrm{~g} / 24 \mathrm{~h}$; range $0.5-28 ; n=13$ ), including 9 with $\geq 3 \mathrm{~g} / 24 \mathrm{~h}$. Renal extramedullary hematopoiesis appeared histologically as an interstitial infiltrate $(n=12)$ and/or a perirenal infiltrate $(n=3)$ or mass-like lesion $(n=1)$. Five were misdiagnosed as interstitial nephritis. Concurrent glomerular disease was prevalent and included fibrillary-like glomerulonephritis $(n=3)$, chronic thrombotic microangiopathy $(n=5)$, focal segmental glomerulosclerosis $(n=6)$, and diabetic glomerulosclerosis $(n=2)$. All patients had an underlying hematologic malignancy: primary myelofibrosis in 9 , myeloproliferative neoplasm not otherwise specified in 1 , essential thrombocythemia in 1, polycythemia vera in 1 , and plasma cell myeloma in 2 . Clinical follow-up was available in 12 patients, mean of 29 months (range 4-120 months). In 10 patients for whom treatment history could be obtained, 9 were treated with chemotherapy, and 1 was treated with steroids. The mean creatinine at last followup was $2 \mathrm{mg} / \mathrm{dl}$ (range 1.2-3.9 $\mathrm{mg} / \mathrm{dl})(n=9)$. Ten patients died in the follow-up period from their underlying hematological disease and had persistent renal disease. The two remaining patients had persistent chronic kidney disease. Renal extramedullary hematopoiesis should be considered in the differential diagnosis of interstitial infiltrates, particularly in the presence of a glomerulopathy and a hematologic malignancy. Modern Pathology (2015) 28, 1574-1583; doi:10.1038/modpathol.2015.117; published online 9 October 2015
\end{abstract}

Extramedullary hematopoiesis is defined as the development and growth of hematopoietic tissue outside the bone marrow. It is associated with a number of disorders in which the normal function of the bone marrow is compromised, and occurs most commonly in primary myelofibrosis and thalassemia. It may also be seen with hereditary spherocytosis, sickle cell anemia, congenital dyserythropoietic anemia, immune thrombocytopenic purpura, and myelodysplastic syndromes, among other conditions. ${ }^{1}$ While the liver, spleen, and lymph nodes are recognized as the organs most frequently involved in this pathological process, several other organs have been reported to be involved by extramedullary hematopoiesis, including the adrenal gland, ${ }^{2}$ breast, ${ }^{3}$ female genital tract, ${ }^{4,5}$ and prostate. ${ }^{6}$ Renal extra-

Correspondence: Dr MP Alexander, MD, Division of Anatomic Pathology, Mayo Clinic, 200 First Street, SW, Rochester, MN 55905, USA.

E-mail: alexander.mariam@mayo.edu

Received 2 August 2015; revised 24 August 2015; accepted 29 August 2015; published online 9 October 2015 medullary hematopoiesis has also been recognized, particularly in post-mortem specimens. ${ }^{7-11}$

In 1962, Pitcock et $a l^{12}$ published their findings in adults with myelofibrosis. Renal extramedullary hematopoiesis was recognized in $35 \%$ of autopsies. In this series of 17 complete autopsies, the kidney was the most commonly affected organ after the liver, spleen, and lymph nodes. Despite this apparent frequency in the post-mortem setting, reports of antemortem renal extramedullary hematopoiesis are restricted to case reports. To date, there is no series on antemortem renal extramedullary hematopoiesis. We hypothesize that under-recognition might explain the lack of such publications.

Glomerular disease has rarely been described in association with renal extramedullary hematopoiesis and includes reports of membranous nephropathy ${ }^{13}$ and mesangioproliferative glomerulonephritis. ${ }^{14}$ Glomerular disease has been described in association with myelodysplastic diseases. ${ }^{15}$

In an effort to characterize clinical presentation, morphological patterns, diagnostic pitfalls, and diagnostic aids of renal extramedullary hematopoiesis, 
we summarize our experience of 14 cases of antemortem renal extramedullary hematopoiesis.

\section{Materials and methods}

\section{Study Population}

This study was approved by the Mayo Clinic Institutional Review Board. Patients with a diagnosis of renal extramedullary hematopoiesis were identified by retrospective review of the renal pathology archived reports at Mayo Clinic (Rochester, MN, USA), from 1994 to 2015, using the keywords 'extramedullary hematopoiesis.' Renal biopsy reports were also searched for biopsies with interstitial inflammation or tubulointerstitial nephritis in patients with a known clinical history of myelofibrosis, myeloproliferative neoplasm/myelodysplasia, sickle cell disease, or thalassemia; slides were reviewed from these cases to evaluate for extramedullary hematopoiesis.

\section{Pathological Studies}

The slides on all renal extramedullary hematopoiesis cases were reviewed. Kidney needle biopsy samples had routine light microscopy, immunofluorescence microscopy, and electron microscopy evaluation. One fine-needle aspirate specimen was stained with hematoxylin and eosin (H\&E). For light microscopy, all needle biopsies were stained with H\&E, periodic acid-Schiff, Masson's trichrome, and Jones methenamine silver. For immunofluorescence, 3 - $\mu$ m cryostat sections were stained, using a Dako Autostainer with polyclonal FITC-conjugated antibodies to IgG, IgM, IgA, C3, C1q, kappa, lambda, fibrinogen, and albumin (Dako, Carpinteria, CA, USA). In one biopsy (patient 5), glomeruli were absent on frozen tissue. Electron microscopy was performed on 13 biopsies. Immunohistochemistry was performed in five cases with a panel that included CD3, CD15, CD20, CD30, CD45, glycophorin, hemoglobin, myeloperoxidase, PAX-5, and S-100.

\section{Clinical Data and Outcomes}

Clinical information including demographic information, presenting clinical and laboratory findings, medical history, treatment, and follow-up data were obtained from referral forms submitted at the time of biopsy and patients' medical records. We studied outcomes to include changes in kidney function at last follow-up to determine improvement or progression of renal disease. Normal kidney function was defined as a final serum creatinine level $<1.4 \mathrm{mg} / \mathrm{dl}$, progressive chronic kidney disease as serum creatinine level $\geq 1.4 \mathrm{mg} / \mathrm{dl}$, or end-stage renal disease if the patient remained on renal replacement therapy or received a kidney transplant. Death due to hematologic disease or kidney failure was another outcome.

\section{Results}

\section{Baseline Clinical and Demographic Data}

Fourteen patients with renal extramedullary hematopoiesis were identified. Thirteen had undergone a kidney needle core biopsy, and one had undergone a fine-needle aspiration biopsy of the kidney. The clinical characteristics of all 14 patients are summarized in Table 1; the cohort consisted of nine men and five women. The mean age at biopsy was 68 years (range 47-87 years). All patients had an underlying hematological disorder: primary myelofibrosis in nine, myeloproliferative neoplasm not otherwise specified in one, essential thrombocythemia in one, polycythemia vera in one, and plasma cell myeloma in two. The hematologic disorder was known before diagnosis of renal extramedullary hematopoiesis in 12 patients. Duration of disease before detection of renal extramedullary hematopoiesis varied. The two patients with plasma cell myeloma had diagnoses of the hematologic neoplasm made close to the time of renal biopsy. In one patient, the diagnosis was made just after the renal biopsy; and in the other, plasma cell myeloma was diagnosed 1 month before detection of renal extramedullary hematopoiesis. The time from diagnosis of primary myelofibrosis to the diagnosis of extramedullary hematopoiesis was 7 to 216 months (mean 83 months). In 11 patients with available data, 9 $(82 \%)$ had extramedullary hematopoiesis identified in one or more other organs, including the liver (4 patients), spleen (7 patients), and lung (1 patient). Comorbidities included hypertension in eight patients, diabetes mellitus in three, gout in three, HIV infection in one, and hepatitis B infection in one.

Renal imaging by ultrasonography was available in eight patients. A perinephric soft tissue mass lesion was observed in the one patient who underwent a fine-needle aspiration biopsy, and three others showed diffuse echogenicity of the kidney. Three patients had normal echogenicity. One patient had enlargement of the kidney.

Renal insufficiency and proteinuria were the most frequent indications for renal needle core biopsy. All patients $(100 \%)$ presented with renal insufficiency. The mean serum creatinine at biopsy was $2.9 \mathrm{mg} / \mathrm{dl}$ (range 1.2-7.3 mg/dl). One patient (patient 6) underwent fine-needle aspiration biopsy for a perirenal mass lesion; this patient also had mild proteinuria and mildly elevated creatinine at the time of the fineneedle aspiration biopsy. Proteinuria was present in all of the 14 patients, with quantitative urinary protein estimation available in 13 (mean $7.9 \mathrm{~g} / 24 \mathrm{~h}$; range 0.5-28), exceeding $3 \mathrm{~g} / 24 \mathrm{~h}$ in 9 (69\%). The two patients with myeloma may have had light chains representing a portion of the proteinuria.

\section{Renal Pathology}

Interstitial lesions. The renal pathology characteristics of the 14 patients are summarized in Table 2 . 
Table 1 Clinical characteristics

\begin{tabular}{|c|c|c|c|c|c|c|c|c|c|c|c|c|}
\hline Patient & $\begin{array}{c}\text { Age/ } \\
\text { gender }\end{array}$ & Renal presentation & $\begin{array}{l}\text { Hematological } \\
\text { disorder }\end{array}$ & $\begin{array}{l}\text { Duration of } \\
\text { hematologic } \\
\text { disorder at the } \\
\text { time of kidney } \\
\text { biopsy (months) }\end{array}$ & $\begin{array}{l}\text { Other sites } \\
\text { of EMH }\end{array}$ & Comorbidities & $\begin{array}{c}\text { Serum } \\
\text { creatinine } \\
\text { at presentation } \\
(\mathrm{mg} / \mathrm{dl})\end{array}$ & $\begin{array}{l}\text { Proteinuria } \\
\quad(g / 24 h)\end{array}$ & Treatment & $\begin{array}{c}\text { Renal } \\
\text { outcome } \\
(S C r, \mathrm{mg} / \mathrm{dl})\end{array}$ & $\begin{array}{l}\text { Patient } \\
\text { outcome }\end{array}$ & $\begin{array}{l}\text { Duration of } \\
\text { follow-up } \\
\text { (months) }\end{array}$ \\
\hline 1 & $47 / \mathrm{M}$ & Acute renal failure & $\begin{array}{l}\text { Plasma cell } \\
\text { myeloma }\end{array}$ & 0 & Liver & HIV, hepatitis B & 5.8 & $\begin{array}{l}3(1+\text { protein } \\
\text { on UA) }\end{array}$ & $\begin{array}{l}\text { Lenalidomide, } \\
\text { bortezomib, } \\
\text { dexamethasone }\end{array}$ & 2.8 & $\begin{array}{l}\text { Deceased; } \\
\text { respiratory } \\
\text { failure from } \\
\text { infection }\end{array}$ & 48 \\
\hline 2 & $87 / \mathrm{M}$ & $\begin{array}{l}\text { Acute renal failure } \\
\text { and proteinuria }\end{array}$ & PMF & 12 & None & $\begin{array}{l}\text { Hypertension, } \\
\text { gout }\end{array}$ & 2.3 & 3.2 & $\begin{array}{l}\text { Maintained on } \\
\text { pomalidomide }\end{array}$ & 3.2 & Deceased & 24 \\
\hline 3 & $61 / \mathrm{M}$ & $\begin{array}{l}\text { Nephrotic syndrome } \\
\text { and renal failure }\end{array}$ & PMF & 7 & $\begin{array}{l}\text { Liver and } \\
\text { spleen }\end{array}$ & $\begin{array}{l}\text { DM, chronic } \\
\text { TTP, } \\
\text { hypertension }\end{array}$ & 1.3 & $>28$ & $\begin{array}{l}\text { Hydroxyurea, } \\
\text { investigational drug } \\
\text { (analog of thalidomide) }\end{array}$ & 1.4 & Deceased & 36 \\
\hline 4 & $78 / \mathrm{M}$ & $\begin{array}{l}\text { Chronic kidney } \\
\text { disease and } \\
\text { nephrotic range } \\
\text { proteinuria }\end{array}$ & PMF & Unknown & None & Unknown & 1.7 & $>10$ & Unknown & Unknown & Deceased & 38 \\
\hline 5 & $72 / \mathrm{M}$ & $\begin{array}{l}\text { Renal failure and } \\
\text { proteinuria }\end{array}$ & $\begin{array}{l}\text { Myeloproliferative } \\
\text { neoplasm, NOS }\end{array}$ & 108 & Spleen & $\begin{array}{l}\text { Hypertension; } \\
\text { gout }\end{array}$ & 3.4 & 3.7 & Steroids & Unknown & Deceased & 46 \\
\hline 6 & 75/M & $\begin{array}{l}\text { Renal failure and } \\
\text { perirenal mass } \\
\text { lesion }\end{array}$ & PMF & 84 & $\begin{array}{l}\text { Spleen, } \\
\text { liver and } \\
\text { lungs }\end{array}$ & None & 1.8 & 0.5 & Hydroxyurea & 1.3 & Deceased & 120 \\
\hline 7 & $56 / \mathrm{M}$ & $\begin{array}{l}\text { Chronic kidney } \\
\text { disease and nephrotic } \\
\text { range proteinuria }\end{array}$ & PMF & 180 & Spleen & None & 2.7 & $>10$ & Anagrelide & 2.4 & Deceased & 10 \\
\hline 8 & $65 / \mathrm{F}$ & $\begin{array}{l}\text { Acute renal failure } \\
\text { and proteinuria }\end{array}$ & PMF & 0 & $\begin{array}{l}\text { Liver and } \\
\text { spleen }\end{array}$ & $\begin{array}{l}\text { Hypertension } \\
\text { and DM }\end{array}$ & 7.3 & Present & Unknown & Unknown & $\begin{array}{l}\text { Not } \\
\text { available }\end{array}$ & NA \\
\hline 9 & $67 / \mathrm{M}$ & $\begin{array}{l}\text { Acute renal failure } \\
\text { and proteinuria }\end{array}$ & ET & 216 & Spleen & $\begin{array}{l}\text { Hypertension, } \\
\text { DM and gout }\end{array}$ & 2.5 & 7 & $\begin{array}{l}\text { Hydroxyurea; } \\
\text { anagrelide }\end{array}$ & 3.9 & Deceased & 5 \\
\hline 10 & $82 / \mathrm{F}$ & $\begin{array}{l}\text { Acute on chronic } \\
\text { renal failure and } \\
\text { proteinuria }\end{array}$ & PMF & Unknown & Unknown & Unknown & 5.6 & 14 & Unknown & Unknown & Deceased & 4 \\
\hline 11 & 73/M & $\begin{array}{l}\text { Renal failure and } \\
\text { proteinuria }\end{array}$ & PMF & Unknown & Unknown & HTN & 1.6 & 11.8 & Unknown & 1.2 & Deceased & 7 \\
\hline 12 & $49 / \mathrm{F}$ & $\begin{array}{l}\text { Renal failure and } \\
\text { proteinuria }\end{array}$ & $\begin{array}{l}\text { Plasma cell } \\
\text { myeloma }\end{array}$ & 1 & Unknown & None & 3.1 & 1.8 & $\begin{array}{l}\text { Cyclophosphamide, } \\
\text { bortezomib, } \\
\text { dexamethasone and } \\
\text { PBSCT }\end{array}$ & 1.2 & $\begin{array}{l}\text { Persistent } \\
\text { renal } \\
\text { dysfunction }\end{array}$ & 10 \\
\hline 13 & $66 / \mathrm{F}$ & $\begin{array}{l}\text { Renal failure and } \\
\text { proteinuria }\end{array}$ & PMF & 216 & Spleen & Hypertension & 1.2 & 0.6 & $\begin{array}{l}\text { Hydrea, anagrelide } \\
\text { and ruxolitinib }\end{array}$ & 1.4 & $\begin{array}{l}\text { Progressive } \\
\text { renal } \\
\text { dysfunction }\end{array}$ & 5 \\
\hline 14 & $79 / \mathrm{F}$ & $\begin{array}{l}\text { Renal failure and } \\
\text { proteinuria }\end{array}$ & PV & 240 & Spleen & Hypertension & 1.2 & 5.0 & Chlorambucil & NA & NA & NA \\
\hline
\end{tabular}

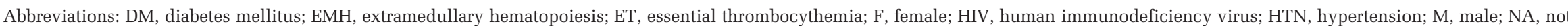

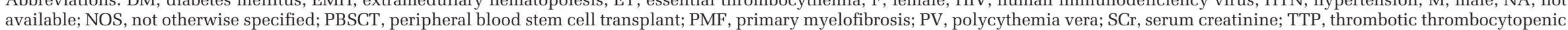
available; NOS, not otherwise specified; PBSCT, peripheral blood ster
purpura; UA, urinalysis.

Note: Conversion factors for units: $\mathrm{SCr}$ in $\mathrm{mg} / \mathrm{dl}$ to $\mu \mathrm{mol} / \mathrm{l}, \times 88.4$. 


\begin{tabular}{|c|c|c|c|c|c|c|c|}
\hline Patient & Biopsy diagnosis & Glomerular pattern & Location of EMH & ATI & $\begin{array}{l}\text { Interstitial } \\
\text { fibrosis }\end{array}$ & IF & Electron microscopy \\
\hline 1 & EMH, 'LHCDD by IF only’ & Mild mesangial sclerosis & Interstitium, diffuse & No & None & $\begin{array}{l}\text { Linear GBM and TBM } \\
\text { with IgG }(2+) \text {, kappa }(2 \\
+) \text {, and lambda (trace) }\end{array}$ & $\begin{array}{l}\text { Normal, preserved } \\
\text { podocyte FP; no evidence } \\
\text { of MIDD }\end{array}$ \\
\hline 2 & FSGS, EMH & $\begin{array}{l}\text { FSGS, segmental endothelial injury } \\
\text { by EM }\end{array}$ & Perirenal soft tissue & No & Moderate & Negative & $\begin{array}{l}\text { Moderate segmental FPE; } \\
\text { segmental endothelial } \\
\text { injury }\end{array}$ \\
\hline 3 & $\begin{array}{l}\text { Diabetic } \\
\text { glomerulosclerosis and } \\
\text { TMA, EMH }\end{array}$ & $\begin{array}{l}\text { Diffuse mesangial sclerosis, } \\
\text { segmental GBM duplication, FSGS }\end{array}$ & Interstitium, diffuse & Yes & Mild & Negative & $\begin{array}{l}\text { Diffuse FPE; segmental } \\
\text { TMA features }\end{array}$ \\
\hline 4 & $\begin{array}{l}\text { Fibrillary-like } \\
\text { glomerulonephritis and } \\
\text { TMA, EMH }\end{array}$ & $\begin{array}{l}\text { Moderate mesangial sclerosis, } \\
\text { segmental GBM duplication; Congo } \\
\text { red-negative }\end{array}$ & Interstitium, diffuse & Yes & Mild & $\begin{array}{l}\text { Granular mesangial and } \\
\text { segmental GBM IgM(2+), } \\
\text { IgA(1+), kappa(1+), } \\
\text { lambda(1+), and C3(2+) }\end{array}$ & $\begin{array}{l}\text { Diffuse FPE, mesangial and } \\
\text { GBM fibrillary deposits } \\
\text { 15-20 nm diameter; } \\
\text { segmental TMA features }\end{array}$ \\
\hline 5 & FSGS, EMH & $\begin{array}{l}\text { FSGS, increased global } \\
\text { glomerulosclerosis }(50 \%)\end{array}$ & $\begin{array}{l}\text { Perirenal soft tissue, } \\
\text { interstitium (medulla), focal, } \\
\text { on previous biopsy }\end{array}$ & No & Mild & NA, inadequate tissue & Diffuse FPE \\
\hline 6 & EMH & NA (fine-needle aspirate) & NA & NA & NA & NA & NA \\
\hline 7 & $\begin{array}{l}\text { Fibrillary-like } \\
\text { glomerulonephritis, EMH }\end{array}$ & $\begin{array}{l}\text { Mild mesangial hypercellularity, } \\
\text { moderate mesangial sclerosis; } \\
\text { Congo red-negative }\end{array}$ & Interstitium, diffuse & None & Moderate & $\begin{array}{l}\text { Granular glomerular IgM } \\
(1-2+) \text { and C3 }(1-2+)\end{array}$ & $\begin{array}{l}\text { Diffuse FPE; mesangial and } \\
\text { GBM fibrillary deposits } \\
11 \mathrm{~nm} \text { diameter }\end{array}$ \\
\hline 8 & $\mathrm{EMH}$ & Normal & $\begin{array}{l}\text { Perirenal soft tissue, } \\
\text { interstitium, focal }\end{array}$ & No & Moderate & Negative & $\begin{array}{l}\text { Moderate segmental FPE } \\
\text { (ischemic) }\end{array}$ \\
\hline 9 & $\begin{array}{l}\text { TMA, diabetic } \\
\text { glomerulosclerosis, EMH, }\end{array}$ & Nodular mesangial sclerosis & $\begin{array}{l}\text { Perirenal soft tissue, } \\
\text { interstitium, focal }\end{array}$ & No & Moderate & Negative & $\begin{array}{l}\text { TMA features segmental } \\
\text { mild FPE }\end{array}$ \\
\hline 10 & FSGS, EMH & $\begin{array}{l}\text { FSGS, increased global } \\
\text { glomerulosclerosis ( } 56 \% \text { ), mild- } \\
\text { moderate mesangial sclerosis }\end{array}$ & Interstitium, multifocal & Yes & Severe & Negative & Diffuse FPE \\
\hline 11 & FSGS, EMH & $\begin{array}{l}\text { FSGS, increased global } \\
\text { glomerulosclerosis ( } 32 \%) \text {, mild- } \\
\text { moderate mesangial sclerosis, } \\
\text { segmental endothelial injury by EM }\end{array}$ & Interstitium, diffuse & No & Moderate & Negative & $\begin{array}{l}\text { Segmental FPE; segmental } \\
\text { endothelial injury }\end{array}$ \\
\hline 12 & $\begin{array}{l}\text { Light-chain cast } \\
\text { nephropathy, EMH }\end{array}$ & NA, normal; Congo red-negative & Interstitium, diffuse & Yes & Mild & $\begin{array}{l}\text { Granular mesangial C3 } \\
\text { (trace); casts lambda ( } 3 \\
+ \text { ), and kappa negative }\end{array}$ & Segmental mild FPE \\
\hline 13 & $\begin{array}{l}\text { Fibrillary-like } \\
\text { glomerulonephritis, TMA, } \\
\text { EMH }\end{array}$ & $\begin{array}{l}\text { Mesangiolysis, mild mesangial } \\
\text { sclerosis, segmental GBM } \\
\text { duplication; Congo red weakly } \\
\text { positive }\end{array}$ & Interstitium, diffuse & Yes & Mild & Negative & $\begin{array}{l}\text { Diffuse FPE; mesangial and } \\
\text { GBM fibrillary deposits } \\
13 \mathrm{~nm} \text { diameter; segmental } \\
\text { GBM multilayering }\end{array}$ \\
\hline 14 & TMA, EMH & $\begin{array}{l}\text { Mesangiolysis, mild mesangial } \\
\text { sclerosis, global GBM duplication }\end{array}$ & $\begin{array}{l}\text { Interstitium, focal. Peritubular } \\
\text { capillaries with circulating } \\
\text { megakaryocytes and erythroid } \\
\text { precursors }\end{array}$ & Yes & Moderate & Negative & $\begin{array}{l}\text { Diffuse FPE; segmental } \\
\text { GBM duplication }\end{array}$ \\
\hline
\end{tabular}

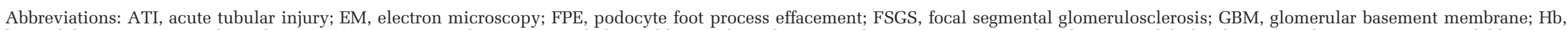

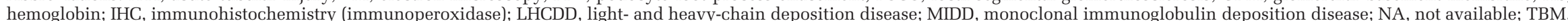
tubular basement membrane; TMA, thrombotic microangiopathy. 
By light microscopy, all biopsies showed trilineage hematopoiesis in areas affected by renal extramedullary hematopoiesis. There was variability in the relative amounts of erythroid and myeloid biopsies. Erythroid cells, identifiable by hyperchromatic round nucleus with clear or pink rings of cytoplasm, were often present in clusters (Figure 1). Megakaryocytes were identifiable by their large size, multilobed nuclei, and large amounts of granular cytoplasm (Figure 1). Myeloid cells often included many eosinophils and eosinophil precursors (Figure 1). In five patients (patients 1, 5, 8, 12, and 14), immunohistochemical stains were performed to confirm the diagnosis. Erythroid cells were identified with hemoglobin or glycophorin (Figure 1). Myeloid precursors were identified by the myeloperoxidase stain (Figure 1), and megakaryocytes were detected by the CD61 stain (Figure 1). One biopsy (patient 12) with plasma cell myeloma showed extramedullary hematopoiesis and concurrent lightchain cast nephropathy. Acute tubular injury was seen in $42 \%$ (5 of 12) of the biopsies. In one biopsy (patient 14) with focal interstitial extramedullary hematopoiesis, many peritubular capillaries demonstrated circulating immature precursors.
There were three recognizable patterns of renal extramedullary hematopoiesis: interstitial infiltration of the renal parenchyma, perirenal extension, and sclerosing renal mass-like lesion. Extramedullary hematopoiesis presenting as an interstitial infiltrate was the most common pattern noted in 12 biopsies, diffuse in seven and focal in five (Figure 2).

Perirenal extension of extramedullary hematopoiesis (Figure 2) was noted in four biopsies, involving the sampled capsule and perirenal adipose tissue. In these biopsies, typical trilineage hematopoiesis was identified. Patient 5 presented clinically with renal failure and proteinuria, but histologically, the lesion was tumor-like. This lesion showed a sclerosing and myxoid stroma characterized by thick collagen bands, thick-walled blood vessels, and entrapped adipose tissue. Within the stroma were large cells dispersed singly and in small clusters, most of which exhibited a single irregular, hyperchromatic nucleus and inconspicuous cytoplasm; a few demonstrated multinucleation (Figure 2). These cells stained with CD61, confirming their megakaryocytic lineage. Erythroid and granulocytic precursors, although present, were sparse and stained with glycophorin and myeloperoxidase, respectively. These findings
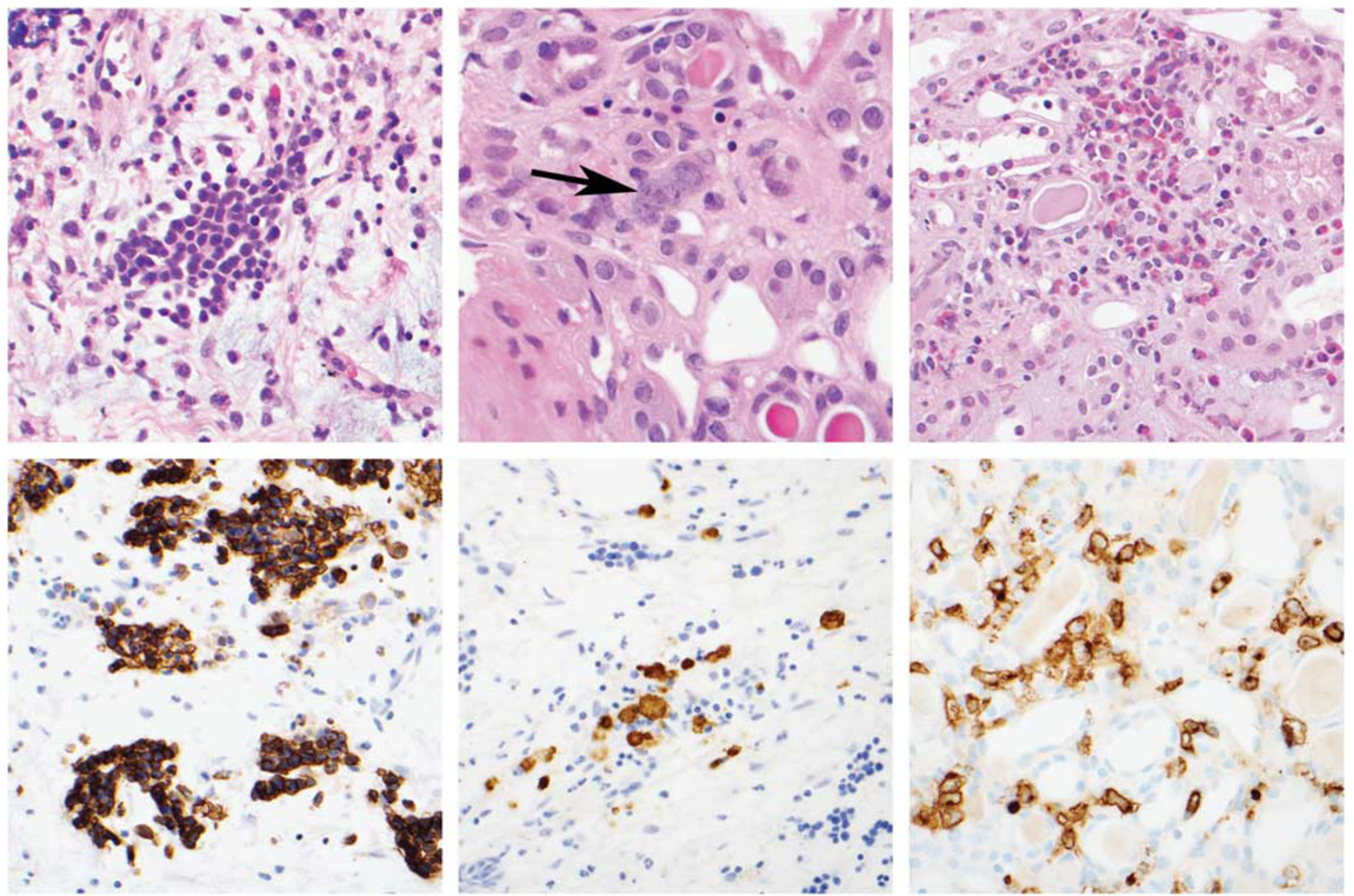

Figure 1 Top left: Erythroid cells were often present in clusters. Top middle: Megakaryocytes were identifiable by large size and multilobated nuclei (arrow). Top right: Myeloid cells often included many eosinophils and eosinophil precursors. Immunohistochemical stains were performed to confirm the diagnosis in a few cases. Bottom left: Erythroid cells were identified with glycophorin. Bottom middle: Megakaryocytes were detected by the CD61 stain. Bottom right: Myeloid precursors were identified by the myeloperoxidase stain. 

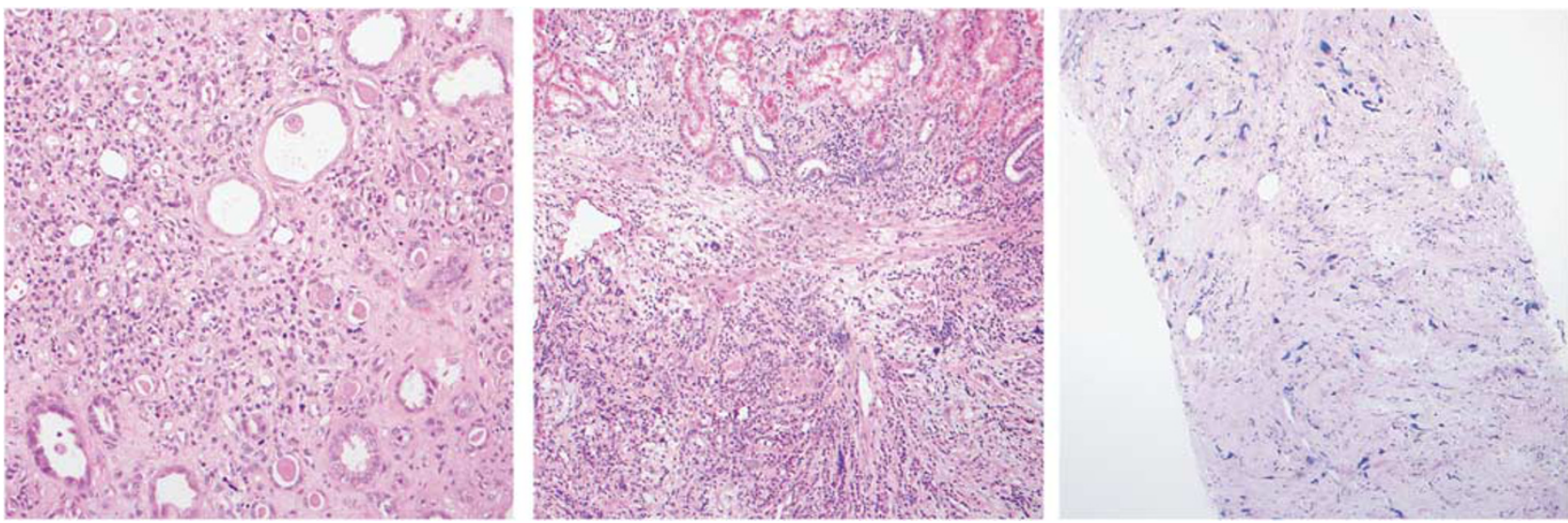

Figure 2 Patterns of renal extramedullary hematopoiesis are depicted here. Left: Interstitial infiltration; middle: perirenal involvement; right: sclerosing mass-like lesions.

resembled a sclerosing extramedullary hematopoietic tumor. This biopsy also showed an interstitial infiltrating pattern. Of interest, 3 years before identification of this mass lesion, the patient had a renal biopsy with foci of extramedullary hematopoiesis on a renal medulla-only tissue sample.

Extramedullary hematopoiesis either mimicked other diagnoses or was misdiagnosed. Five biopsies had been misdiagnosed as tubulointerstitial nephritis. The presence of many eosinophils and erythroid clusters resembling lymphoid cells were misleading features that likely led to an erroneous diagnosis of tubulointerstitial nephritis. The presence of scattered large megakaryocytes and myeloid precursors, often admixed in a fibrotic background, was a helpful diagnostic clue. The absence of tubulitis was a pertinent negative finding. In another biopsy, a focus of extramedullary hematopoiesis was overlooked as nonspecific inflammation. In patient 1 , the infiltrate mimicked Hodgkin lymphoma in that the lobated megakaryocytes resembled Reed-Sternberg cells. Positive staining of the cells for CD61 and negative staining for CD15, CD30, and PAX-5 confirmed their megakaryocytic lineage. In patient 12 , in addition to the characteristic trilineage hematopoiesis, there was an apparent increase in immature myeloid cells. The left-shifted granulocytic precursors stained with myeloperoxidase stain and coexpressed CD33 and lysozyme (partial). Acute myeloid leukemia was excluded because the immature cells were mixed with other hematopoietic precursors, and they were negative for CD34 and CD117. In patient 5, the differential diagnosis for the sclerosing mass-like lesion included sclerosing liposarcoma, sarcomatoid carcinoma, and myelolipoma.

Glomerular lesions. Glomeruli were present for light microscopy in all 13 needle core biopsy samples (mean number of glomeruli 19, range 5-40). Ten patients had glomerular diseases, which sometimes overlapped: focal segmental glomerulosclerosis $(n=6)$, chronic thrombotic microangiopathy $(n=5)$, fibrillary- like glomerulonephritis $(n=3)$, and diabetic glomerulosclerosis $(n=2)$. Of the six patients with focal segmental glomerulosclerosis, two had diffuse podocyte foot process effacement and nephrotic range proteinuria, compatible with a primary podocytopathy. Chronic thrombotic microangiopathy was characterized histologically as glomerular basement membrane multilayering and enlarged endothelial cells in all five patients (Figure 3). Mesangiolysis was noted by light microscopy in two of these patients. No active thrombi were identified in any biopsies. Two other patients had ultrastructural evidence of segmental endothelial cell injury, but the extent of involvement was insufficient to be categorized as chronic thrombotic microangiopathy.

Three biopsies (patients 4, 7, and 13) had a fibrillary glomerulonephritis-like pattern that has not been well described in the literature (Figure 3). Of interest, none of these showed bright staining for IgG that is typical of fibrillary glomerulonephritis. Two biopsies showed glomerular staining for IgM and C3, and one showed additional lesser staining for IgA, kappa, and lambda; these cases were Congo red-negative. Immunofluorescence studies following pronase digestion of the paraffin-embedded material was performed in two biopsies (patients 4 and 13) with antibodies to IgA, IgG, IgM, C1q, kappa, and lambda light chain; both were negative. One biopsy (patient 13) with fibrillary-like deposits by EM showed negative staining of glomeruli by IF. This last biopsy also showed weak Congo red-positive glomerular staining; the material was not identifiable by mass spectrometry.

\section{Follow-Up}

Clinical follow-up data were available in 12 patients at a mean of 29 months post biopsy (range 4-120). In 10 of the patients for whom treatment history could be obtained, 9 were treated with chemotherapy, and 1 was treated with steroids. The mean 

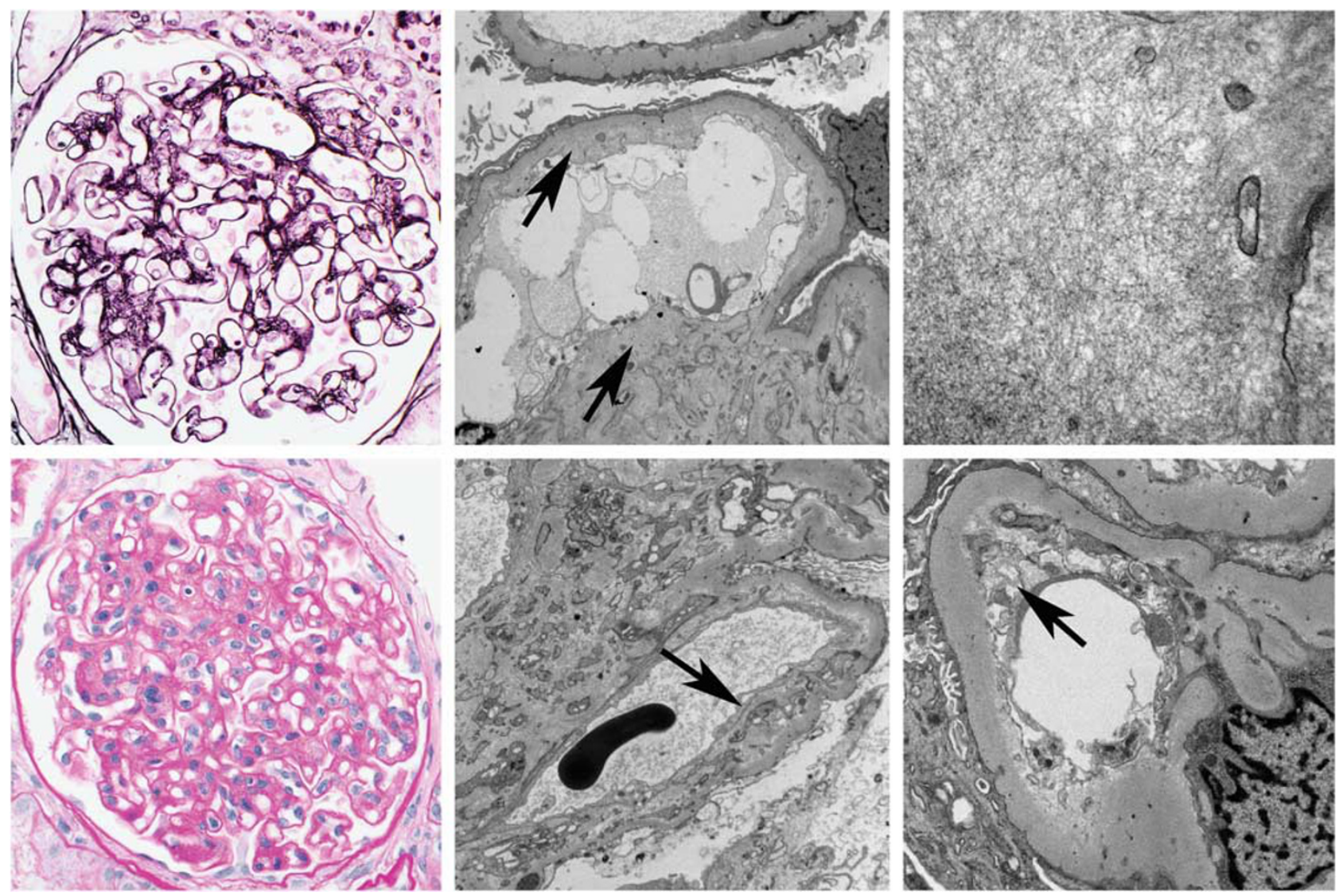

Figure 3 Glomerular pathology may be seen in patients with extramedullary hematopoiesis. Top left: The silver stain demonstrates mesangial expansion by silver negative material. Top middle: Ultrastructural studies show patchy deposits of fibrillary material in the mesangium (arrow) as well as along subendothelial spaces (arrow). Top right: A high-power view demonstrates randomly oriented nonbranching fibrils. Bottom left: The glomerulus demonstrates thickened peripheral capillary loops with subendothelial lucency and basement membrane remodeling, features of chronic thrombotic microangiopathy. Bottom middle and left: Ultrastructural findings include endothelial swelling, subendothelial lucency, and cellular interposition (arrows). Mesangiolysis is also seen in the bottom middle figure.

serum creatinine at follow-up was $2.1 \mathrm{mg} / \mathrm{dl}$ (range $1.2-3.9 \mathrm{mg} / \mathrm{dl}$ ) ( $n=9 ; 4$ unknown). Five patients had improved serum creatinine by at least $0.3 \mathrm{mg} / \mathrm{dl}$. Ten of the patients died: in all, the cause of death was attributed to complications of the malignancy, and all had renal insufficiency. The remaining two had progressive chronic kidney disease.

\section{Discussion}

To our knowledge, this is the first series of antemortem renal extramedullary hematopoiesis. Renal extramedullary hematopoiesis occurred in the setting of hematological malignancies in all of our patients. Myeloproliferative neoplasms, including primary myelofibrosis, essential thrombocythemia, and an unclassified chronic myeloid neoplasm were the most common underlying hematologic disorders both in our series and in available literature. ${ }^{8,10,13,14,16-18}$ In a series of non-hepatosplenic extramedullary hematopoiesis by Koch et al., ${ }^{1}$ primary myelofibrosis was the underlying hematologic disorder in $67 \%$ of patients.
Renal extramedullary hematopoiesis, occurring in the setting of plasma cell myeloma, as seen in two of our patients, has been reported previously. ${ }^{11,19}$ Chronic myelomonocytic leukemia has also been associated with renal extramedullary hematopoiesis. ${ }^{20}$ Although not seen in this series, renal extramedullary hematopoiesis may also occur in benign hematological conditions such as thalassemia ${ }^{21}$ and congenital anemia. Non-neoplastic and non-hematologic scenarios with renal extramedullary hematopoiesis include cystic renal dysplasia. Kakkar et al. ${ }^{22}$ in a histomorphological study of renal dysplasia observed extramedullary hematopoiesis in $98 \%$ of their cases. Renal extramedullary hematopoiesis has also been described in renal allografts. ${ }^{23}$

Although in the majority of published cases and in our data the primary hematologic disorder antedates the diagnosis of renal extramedullary hematopoiesis ( $83 \%$ of our patients), it is not the rule. In two patients (1 and 8), a diagnosis of plasma cell myeloma and myeloproliferative neoplasm was made following the detection of renal extramedullary hematopoiesis. In the two previously reported cases 
of renal extramedullary hematopoiesis and plasma cell myeloma, ${ }^{11,19}$ the renal diagnosis of extramedullary hematopoiesis antedated the diagnosis of plasma cell myeloma. ${ }^{11,19}$

The most common indication for renal biopsy was renal dysfunction, noted in $100 \%$ of the cases. The explanation for this can be manifold. Direct tissue infiltration by the hemopoietic cells compromises both functional renal parenchyma and renal vasculature. Extramedullary hematopoiesis involving the capsule and pericapsular tissue can encase the kidney, simulating the Page kidney. ${ }^{24}$ Extrinsic infiltration (as noted in 50\% of our cases) can also cause hydronephrosis and hydroureter with resultant obstructive uropathy and acute renal failure. ${ }^{12,14}$ In some situations, as seen in patient 8 , both processes may occur. Renal dysfunction might also be attributed to the hematologic process rather than the extramedullary hematopoiesis. Acute tubular injury (seen in $42 \%$ of the biopsy cases) may be because of chemotherapy-related toxicity, as has been described in patients treated with anagrelide. ${ }^{25}$ Acute tubular injury may also be due to cast nephropathy (as in patient 12). Although not seen in our series, renal extramedullary hematopoiesis has been associated with renal calculi, related to high cell turnover and increased urates from the underlying hematological process. ${ }^{12}$

The other main indication for biopsy in this series was proteinuria and, indeed, most biopsies with extramedullary hematopoiesis showed a concurrent glomerular disease: fibrillary-like glomerulonephritis, chronic thrombotic microangiopathy, focal segmental glomerulosclerosis, or nodular diabetic glomerulosclerosis. The glomerular disease patterns other than diabetic glomerulosclerosis are likely related to the renal extramedullary hematopoiesis or the underlying hematologic malignancy. Focal segmental glomerulosclerosis (patients 2, 3, 5, 6, 10, and 11), chronic thrombotic microangiopathy (patients 3,4, 9,13, and 14), and mesangial sclerosis are part of the spectrum of glomerular abnormalities described in the setting of myeloproliferative neoplasms, and nephrotic range proteinuria is a common presentation with these patterns of injury. ${ }^{15} \mathrm{In}$ two of our patients with focal segmental glomerulosclerosis, there was diffuse podocyte foot process effacement and nephrotic range proteinuria of $>10 \mathrm{~g}$ per day, raising the possibility of a primary podocytopathy as a cause for the proteinuria. Hemopoietic cells produce circulating soluble factors and chemokines, which might incite podocyte injury. ${ }^{14}$ Fibrillary glomerulonephritis and amyloidosis, often seen in the setting of hematological malignancies, are common causes of proteinuria. ${ }^{26,27}$ Three of our biopsies showed fibrillary glomerular deposits; all were from patients with primary myelofibrosis. These biopsies, diagnosed as fibrillary-like glomerulonephritis, were unusual as they lacked the characteristic IgG immunoreactivity; two stained with IgM, and only one had weak light-chain staining with both kappa and lambda. Immunofluorescence staining on pronase-digested paraffin sections was negative in two of these cases with tissue available; this staining result argues against a glomerulonephritis with 'masked' deposits. ${ }^{28}$ There is one published report of IgM fibrillary glomerulonephritis in a young child with myelodysplastic syndrome. ${ }^{26}$ The third fibrillary-like glomerulonephritis case was an unusual type of weakly congophilic fibrillary deposition, suspicious for amyloidosis, which could not be characterized by mass spectrometry. It, too, demonstrated isolated weak IgM immunoreactivity. The high incidence of glomerular disease in these patients may have represented a selection bias as proteinuria may have triggered the treating physicians to perform kidney biopsy, although all these patients also had renal insufficiency.

The radiologic findings in renal extramedullary hematopoiesis vary. In our series, the most common abnormality was diffusely increased renal echogenicity. Bilateral enlargement of kidneys, mass-like lesions, and encasement of kidneys with pelviureteric obstruction have been described.1,8,13,17,18,29 Experienced radiologists in the appropriate clinical scenario make a presumptive diagnosis of extramedullary hematopoiesis based on typical findings on computed tomography or magnetic resonance imaging. ${ }^{30}$ This may account for the smaller numbers of antemortem renal extramedullary hematopoiesis reported.

Antemortem diagnosis of renal extramedullary hematopoiesis may be challenging. In many of our cases, the diagnosis was not readily apparent. The closest mimic of the interstitial pattern of renal extramedullary hematopoiesis is tubulointerstitial nephritis, particularly with the eosinophil precursors that may be interpreted as eosinophils in an allergic interstitial nephritis. Another diagnostic dilemma we encountered was differentiating it from Hodgkin's lymphoma. An appropriate immunohistochemistry panel can help distinguish these entities. Differentiating benign extramedullary hematopoiesis with a predominance of a single hematopoietic cell line from a neoplastic myeloid proliferation, such as myeloid sarcoma, is important and is particularly challenging in the case of differentiated myeloid sarcoma. Unilineage proliferation, large islands of immature myeloid precursors, the presence of eosinophilic myelocytes, and immunostaining with CD34 and terminal deoxynucleotidyl transferase (indicating a blast component) point to neoplastic proliferations. ${ }^{31}$ At times, benign extramedullary hematopoiesis may coexist with neoplastic infiltrates as was seen in patient 13, which had an atypical plasma cell infiltrate. ${ }^{11,29}$ The capsular and perirenal infiltrative pattern of extramedullary hematopoiesis can mimic a myelolipoma, particularly when admixed with fat. The presence of megakaryocytes in the kidney in patients with a hematological disorder is a helpful clue. The third 
histologic pattern of renal extramedullary hematopoiesis is of a mass lesion as in patient 5 (previously published). ${ }^{32}$ This was diagnosed as a sclerosing extramedullary hematopoietic tumor ${ }^{33}$ and presented as a retroperitoneal sclerosing spindle cell tumor. The differential diagnosis in this case includes sclerosing liposarcoma, carcinoma with sarcomatoid features, and infiltrating high-grade carcinoma. In patient 14, the immature hematopoietic precursors circulating in glomerular and peritubular capillaries (specifically the large megakaryocytes) drew attention to the relatively small foci of renal extramedullary hematopoiesis, which might otherwise have been missed. However, a note of caution, nucleated red blood cells, often seen in the setting of sepsis ${ }^{34}$ may be detected in the vasa recta and should not be misinterpreted as renal extramedullary hematopoiesis.

One cannot underplay the value of accurately diagnosing renal extramedullary hematopoiesis. When there is radiological evidence of large nodular masses, a fine-needle aspiration cytology or needle biopsy can avert an unnecessary nephrectomy. Renal involvement by neoplastic hematopoietic infiltrates warrants tailored chemotherapy, whereas benign renal extramedullary hematopoiesis is treated only if there is significant renal functional impairment. Progressive renal dysfunction can be prevented with systemic chemotherapy, ${ }^{18}$ as was seen in two of our patients. The evolution of intrarenal extramedullary hematopoiesis in patient 6 to a sclerosing extramedullary hematopoietic tumor in 3 years suggests a role for progressive fibrosis.

It is not readily apparent why extramedullary hematopoiesis occurs in organs such as the kidney, which are not commonly involved in extramedullary hematopoiesis. Mechanisms have been proposed to explain the pathophysiology of renal extramedullary hematopoiesis. The 'splenic filtration theory' suggests that the spleen serves as a filtration barrier to displaced hematopoietic stem cells. ${ }^{35}$ Splenectomy would then be expected to increase the occurrence of non-hepatosplenic extramedullary hematopoiesis. ${ }^{1}$ In our series, among those with available radiological and clinical data, none had documented evidence of splenectomy. This suggests that alternate mechanisms exist for the development of renal extramedullary hematopoiesis. Do hematopoietic elements arise from mesenchymal progenitor cells, which had once participated in embryonic hematogenesis, and then undergo proliferation in disease-related stimulating conditions? The presence of islands of extramedullary hematopoiesis amidst myelomonocytic cells ${ }^{29}$ could result from overproduction of the granulocytemacrophage, colony-stimulating factor. This observation lends support to the 'redirected differentiation theory,' that is, there are circulating factor(s) that induce adult stem cell populations to differentiate into cells of the hematopoietic lineage. ${ }^{1}$

In conclusion, renal extramedullary hematopoiesis should be considered in the differential of patients with hematological malignancies who present with renal dysfunction and proteinuria. Histologically, the interstitial lesion is frequently confused with tubulointerstitial nephritis. Glomerular diseases are present in the majority of patients and include chronic thrombotic microangiopathy, fibrillarylike glomerulonephritis, and focal segmental glomerulosclerosis.

\section{Acknowledgments}

We thank Mrs Denise Chase from Mayo Clinic for her help with the preparation of this manuscript.

\section{Disclosure/conflict of interest}

The authors declare no conflict of interest.

\section{References}

1 Koch CA, Li CY, Mesa RA et al. Nonhepatosplenic extramedullary hematopoiesis: associated diseases, pathology, clinical course, and treatment. Mayo Clin Proc 2003;78:1223-1233.

2 Keikhaei B, Shirazi AS, Pour MM. Adrenal extramedullary hematopoiesis associated with beta-thalassemia "major. Hematol Rep 2012;4:e7.

3 Harbin LJ, Burnett S, Ghilchik M et al. Extramedullary haematopoiesis in a hyalinized mammary fibroadenoma. Histopathology 2002;41:475-477.

4 Sirgi KE, Swanson PE, Gersell DJ. Extramedullary hematopoiesis in the endometrium. Report of four cases and review of the literature. Am J Clin Pathol 1994;101:643-646.

5 Valeri RM, Ibrahim N, Sheaff MT. Extramedullary hematopoiesis in the endometrium. Int J Gynecol Pathol 2002;21:178-181.

6 Humphrey PA, Vollmer RT. Extramedullary hematopoiesis in the prostate. Am J Surg Pathol 1991;15: 486-490.

7 Gibbins J, Pankhurst T, Murray J et al. Extramedullary haematopoiesis in the kidney: a case report and review of literature. Clin Lab Haematol 2005;27:391-394.

8 Glew RH, Haese WH, McIntyre PA. Myeloid metaplasia with myelofibrosis. The clinical spectrum of extramedullary hematopoiesis and tumor formation. Johns Hopkins Med J 1973;132:253-270.

9 Holt SG, Field P, Carmichael P et al. Extramedullary haematopoiesis in the renal parenchyma as a cause of acute renal failure in myelofibrosis. Nephrol Dial Transplant 1995;10:1438-1440.

10 Moskovitz B, Malberger E, Brenner B et al. Renal extramedullary hematopoiesis simulating hypernephroma. Eur Urol 1991;19:343-345.

11 Nasr SH, Alobeid BB, Otrakji JA et al. Myeloma cast nephropathy, direct renal infiltration by myeloma, and renal extramedullary hematopoiesis. Kidney Int 2008;73:517-518.

12 Pitcock JA, Reinhard EH, Justus BW et al. A clinical and pathological study of seventy cases of myelofibrosis. Ann Intern Med 1962;57:73-84.

13 Pamuk ON, Pamuk GE, Altiparmak MR et al. Nephrotic syndrome associated with agnogenic myeloid metaplasia. Leuk Lymphoma 2002;43:661-663. 
14 Perazella MA, Buller GK. Nephrotic syndrome associated with agnogenic myeloid metaplasia. Am J Nephrol 1994;14:223-225.

15 Said SM, Leung N, Sethi S et al. Myeloproliferative neoplasms cause glomerulopathy. Kidney Int 2011;80: 753-759.

16 Ablett MJ, Vosylius P. Perirenal extramedullary haematopoeisis in myelofibrosis demonstrated on computed tomography. Br J Haematol 2004;124:406.

17 Schnuelle P, Waldherr R, Lehmann KJ et al. Idiopathic myelofibrosis with extramedullary hematopoiesis in the kidneys. Clin Nephrol 1999;52:256-262.

18 Woodward N, Ancliffe P, Griffiths MH et al. Renal myelofibrosis: an unusual cause of renal impairment. Nephrol Dial Transplant 2000;15:257-258.

19 Tsao L, Siegel DS, Zeveloff S et al. An unusual finding in the renal medulla. Am J Kidney Dis 2005;46:780-786.

20 Hyams ES, Gupta R, Melamed J et al. Renal involvement by chronic myelomonocytic leukemia requiring nephroureterectomy. Rev Urol 2009;11:33-37.

21 Saisorn I, Leewansangtong S, Sukpanichnant S et al. Intrarenal extramedullary hematopoiesis as a renal mass in a patient with thalassemia. J Urol 2001;165: 507-508.

22 Kakkar N, Menon S, Radotra BD. Histomorphology of renal dysplasia - an autopsy study. Fetal Pediatr Pathol 2006;25:73-86.

23 Nast CC, Barba L, Danovitch GM et al. Intrarenal extramedullary erythropoiesis in renal allograft fineneedle aspirates. Am J Kidney Dis 1995;25:46-50.

24 Sufrin G. The Page kidney: a correctable form of arterial hypertension. J Urol 1975;113:450-454.

25 Rodwell GE, Troxell ML, Lafayette RA. Renal tubular injury associated with anagrelide use. Nephrol Dial Transplant 2005;20:988-990.
26 Shim YH, Lee SJ, Sung SH. A case of fibrillary glomerulonephritis with unusual IgM deposits and hypocomplementemia. Pediatr Nephrol 2008;23:1163-1166.

27 Kornblihtt LI, Vassalllu PS, Heller PG et al. Primary myelofibrosis in a patient who developed primary biliary cirrhosis, autoimmune hemolytic anemia and fibrillary glomerulonephritis. Ann Hematol 2008;87: 1019-1020

28 Larsen CP, Messias NC, Walker PD et al. Membranoproliferative glomerulonephritis with masked monotypic immunoglobulin deposits. Kidney Int 2015.

29 Bane AL, Enright H, Sweeney EC. Chronic myelomonocytic leukemia revealed by uncontrollable hematuria. Arch Pathol Lab Med 2001;125:657-659.

30 Alorainy IA, Al-Asmi AR, del Carpio R. MRI features of epidural extramedullary hematopoiesis. Eur J Radiol 2000;35:8-11.

31 O'Malley DP. Benign extramedullary myeloid proliferations. Mod Pathol 2007;20:405-415.

32 Sukov WR, Remstein ED, Nascimento AG et al. Sclerosing extramedullary hematopoietic tumor: emphasis on diagnosis by renal biopsy. Ann Diagn Pathol 2009;13: 127-131.

33 Remstein ED, Kurtin PJ, Nascimento AG. Sclerosing extramedullary hematopoietic tumor in chronic myeloproliferative disorders. Am J Surg Pathol 2000;24: $51-55$.

34 Desai S, Jones SL, Turner KL et al. Nucleated red blood cells are associated with a higher mortality rate in patients with surgical sepsis. Surg Infect 2012;13: 360-365.

35 Wolf BC, Neiman RS. Hypothesis: splenic filtration and the pathogenesis of extramedullary hematopoiesis in agnogenic myeloid metaplasia. Hematol Pathol 1987;1: 77-80. 